\title{
Primary Burkitt lymphoma of the thyroid gland: case report of an exceptional type of thyroid neoplasm and review of the literature
}

Mohamed Allaoui ${ }^{1 *}$, Ilias Benchafai ${ }^{2}$, El Mehdi Mahtat ${ }^{3}$, Safae Regragui ${ }^{3}$, Adil Boudhas ${ }^{1}$, Mustapha Azzakhmam', Mohammed Boukhechba ${ }^{1}$, Abderrahmane Al Bouzidi ${ }^{1}$ and Mohamed Oukabli ${ }^{1}$

\begin{abstract}
Background: Primary thyroid lymphoma is an uncommon pathological entity that accounts for only 1 to $5 \%$ of all thyroid malignancies. Primary Burkitt lymphoma of the thyroid gland is very rare. This article presents the first Moroccan case of a primary BL of the thyroid to be reported in the literature to date.

Case presentation: We describe here a case of a 70-year-old male who developed a rapidly enlarging thyroid gland with progressive symptoms of compression. Core biopsy confirmed the diagnosis of Burkitt lymphoma. The patient died of septic shock, 2 weeks after the first cycle of appropriate therapeutic chemotherapy.

Conclusions: This presentation emphasizes the importance of considering lymphoma when dealing with a thyroid mass, as its management is different from that of other thyroid pathologies, and affords an opportunity to review a very rare type of primary thyroid lymphoma.
\end{abstract}

Keywords: Burkitt lymphoma, Thyroid gland, Chemotherapy

\section{Background}

Primary Burkitt lymphoma (BL) of the thyroid gland is a very uncommon pathological entity with a few isolated case reports in adult patients $[1,2]$.

This highly aggressive malignancy arises from Blymphoid cells. It presents usually as a rapidly expanding thyroid mass causing compressive symptoms.

To the best of our knowledge, this article reports the first Moroccan case of a primary BL of the thyroid to be reported in the literature to date.

BL should be promptly recognized because its management is quite different from the treatment of other neoplasms of the thyroid gland. Moreover, this disease is quite curable if diagnosed early and treated appropriately.

\footnotetext{
* Correspondence: allaoui.m1@gmail.com

'Department of Pathology, Military General Hospital Mohammed V, Mohammed V Souissi University - Faculty of Medicine and Pharmacy of Rabat, Hay Riad, Rabat 10000, Morocco

Full list of author information is available at the end of the article
}

\section{Case presentation}

A 70-year-old male presented a rapidly expanding mass of the neck associated with history of airway compression symptoms; progressive dyspnea and dysphonia lasting for 4 weeks, in a context of apyrexia and impairment of general condition. The patient was admitted to the hospital because of increasing dyspnea and urgently received a tracheostomy.

A biopsy of the cervical mass was carried out and the histological examination showed diffuse infiltration of the thyroid gland by a monotonous population of atypical intermediate-sized lymphoid cells (Fig. 1). These last possess scanty amphophilic to basophilic cytoplasm with centrally located nuclei of irregular shape, displaying dispersed basophilic chromatin, and frequent apoptotic figures (Fig. 2). Scattered tingible body type macrophages were also present. Little residual thyroid follicles and some areas of necrosis was observed.

Immunohistochemical staining was then performed and the tumour cells were positive for CD20, CD10 and 


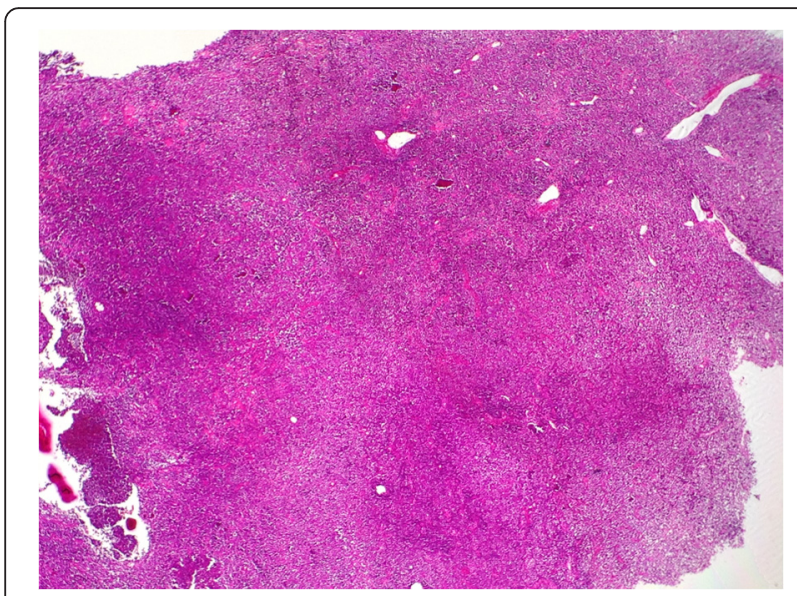

Fig. 1 Low magnification showing a diffuse infiltration of atypical lymphoid cells in the thyroid gland (haematoxylin \& eosin stain, $\times 50$ )

BCL6. Ki-67 showed proliferation index approaching $100 \%$. CD3 and CD5 stained the background T cells (Fig. 3). Immunoreactivity for Epstein-Barr virus (EBV) was negative. The diagnosis of $\mathrm{BL}$ was confirmed on fluorescence in situ hybridisation that showed tumour cell positivity for the $t(8 ; 14)$ translocation. Bone marrow examination was normal.

The patient was transferred to the Clinical Haematology department. On physical examination, he was apyretic and hemodynamically stable with a cervical armouring by a huge mass of hard consistency. Neurological examination shows no sensorimotor deficits.

Other systemic examinations were normal, without any palpable lymphadenopathy or organomegaly.

The computerized tomography (CT) scan showed a heterogeneous process of the thyroid gland measuring $10.5 \times 8.2 \times 6.5 \mathrm{~cm}$ in size, extending up towards the

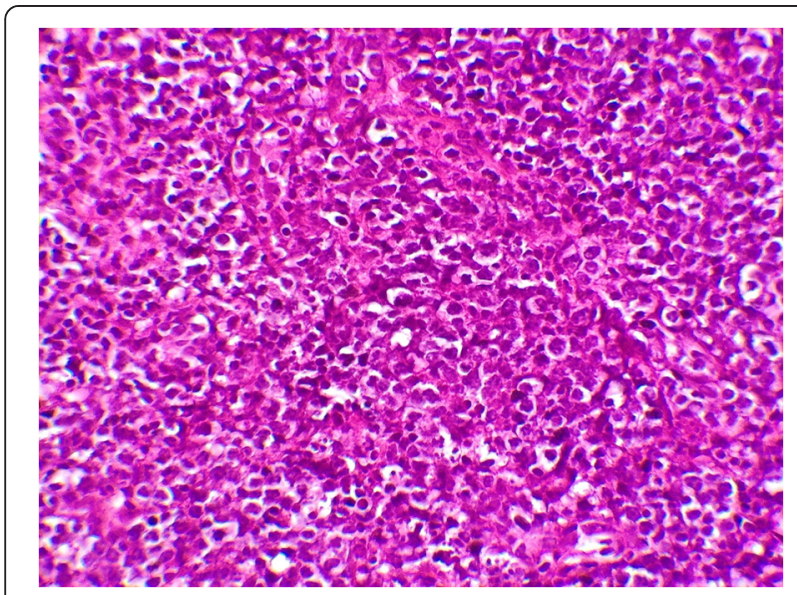

Fig. 2 Higher magnification showing a monotonous population of intermediate-sized lymphoid cells with scant dark blue cytoplasm, small cytoplasmic vacuoles and tingible-body macrophages (haematoxylin \& eosin stain, $\times 400$ ) laryngeal region, infiltrating the right vocal cord and reducing the laryngeal lumen (Fig. 4).

The thoraco-abdominal CT scan showed no other localization.

The examination of the cephalorachidian liquid showed no central nervous system involvement. The patient was diagnosed with thyroidal Burkitt lymphoma, stage I of Murphy [3].

After cardiac, renal and liver functions assessment, the patient received chemotherapy according to the LMBA02 protocol [4], group A (Age $>60$ years, no CNS nor bone marrow involvement), with a first course of COP (Cyclophosphamide, Vincristine and Prednisone) and intrathecal Methotrexate, followed a week after by a course of R-COPADEM (Rituximab at day 0 and day 6 , Cyclophosphamide day 2,3 and 4, Prednisone from day 1 to 5, Doxorubicineat day 2, high dose Methotrexate at day 1 with folic acid rescue from day 2 to day 6 and intrathecal chemotherapy at day 2 and day 6).

At day 15 of chemotherapy, the patient developed febrile neutropenia, refractory to broad-spectrum antibiotics and antifungals. The evolution was marked by the installation of a septic shock with acute respiratory distress syndrome that led to his transfer to intensive care unit where he was intubated and ventilated. The patient died 2 days after.

\section{Discussion}

Primary thyroid lymphoma (PTL) is defined as a lymphoma involving only the thyroid gland or the thyroid gland and adjacent (regional) neck lymph nodes, without contiguous spread or distant metastases from other areas of involvement at diagnosis [5].

PTL is an uncommon pathological entity that accounts for only 1 to $5 \%$ of all thyroid malignancies, comprises approximately $2 \%$ of all malignant extra nodal lymphomas and which predominantly originate from B lymphocytes $[5,6]$.

The common histological subtypes are diffuse large Bcell lymphoma and mucosa-associated lymphoid tissue (MALT) lymphoma [6-9]. Primary Burkitt lymphoma of the thyroid is very rare with a few isolated case reports (Table 1) [1-3, 10, 11].

Burkitt lymphoma is a highly aggressive disease that is endemic in Africa and sporadic in other parts of the world. The endemic variant is associated with EpsteinBarr virus.

$\mathrm{BL}$ was one of the first tumours shown to have a chromosomal translocation that activates an oncogene $(c-M Y C)[12,13]$.

Normally, the thyroid gland does not contain native lymphoid tissue, therefore, the intrathyroid lymphoid tissue that causes thyroid lymphoma comes from the migration of lymphoid tissue into the thyroid during an 


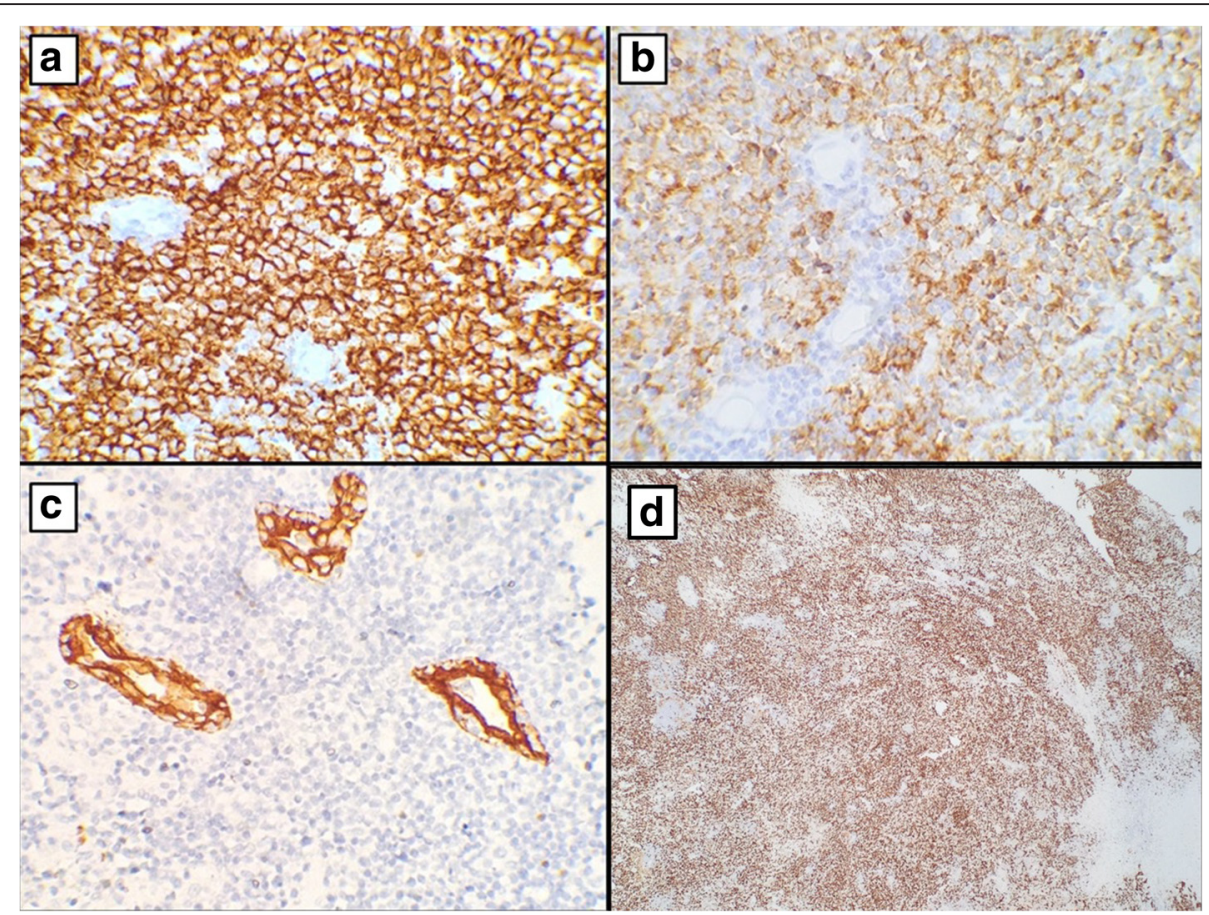

Fig. 3 Immunohistochemical staining revealed the expression of CD20 (a) and CD10 (b) by the neoplastic cells. Keratin highlights the lymphoepithelial lesions (c). Ki-67 immunostaining showed a high proliferation index (d)

inflammatory or immunologic process. The most common condition resulting in lymphoid migration is autoimmune thyroiditis (i.e., Hashimoto's thyroiditis) [14-16]. Large adult population-based as well as retrospective clinicopathological case series suggest that primary thyroid Non-Hodgkin lymphoma NHL typically occur in middle to older-aged persons and have a predilection for females (it have also shown that patients with chronic lymphocytic thyroiditis have a greater risk of subsequently developing thyroid lymphoma when compared to age and gender matched normal individuals) [5, 6, 16-21].

Clinically, lymphomas originating in the thyroid can frequently mimic anaplastic thyroid carcinoma in that both have similar clinical characteristics of rapid growth, which might be associated with compression symptoms dyspnea, dysphagia, pain and hoarseness of voice [2, 22-25].

Ultrasonography is generally the initial diagnostic modality used in the workup of thyroid enlargement and nodules. Although nonspecific, there are certain characteristics that

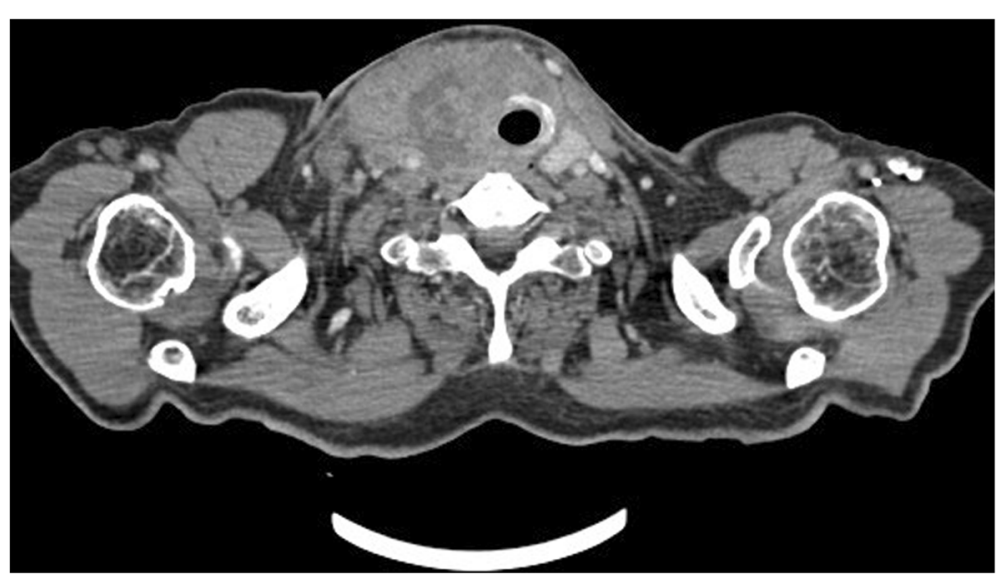

Fig. $4 \mathrm{CT}$ showing a large heterogeneous mass of the thyroid gland 
Table 1 Clinical and pathological characteristics of patients with primary Burkitt lymphoma of the thyroid gland in the literature

\begin{tabular}{|c|c|c|c|c|c|c|c|c|c|}
\hline Author & $\begin{array}{l}\text { Age } \\
\text { (year) }\end{array}$ & Sex & Clinical presentation & $\begin{array}{l}\text { Size of } \\
\text { tumor } \\
(\mathrm{cm})\end{array}$ & Histology & $\begin{array}{l}\text { Translocation } \\
\text { type }\end{array}$ & Treatment & $\begin{array}{l}\text { Follow- } \\
\text { up time } \\
\text { (month) }\end{array}$ & Evolution \\
\hline Our case & 70 & M & $\begin{array}{l}\text { Rapidly expanding } \\
\text { mass of the neck } \\
\text { associated with } \\
\text { airway compression } \\
\text { symptoms }\end{array}$ & 10.5 & $\begin{array}{l}\text { Burkitt } \\
\text { lymphoma }\end{array}$ & t $(8 ; 14)$ & $\begin{array}{l}\text { chemotherapy according } \\
\text { to the LMBA02 protocol; } \\
\text { with a first course of COP } \\
\text { and intrathecal } \\
\text { Methotrexate, followed by } \\
\text { a course of R-COPADEM. }\end{array}$ & $\begin{array}{l}\text { Patient } \\
\text { died }\end{array}$ & $\begin{array}{l}\text { The patient } \\
\text { died of septic } \\
\text { shock, } 2 \text { weeks } \\
\text { after the first } \\
\text { cycle of } \\
\text { chemotherapy }\end{array}$ \\
\hline $\begin{array}{l}\text { Camera et al. } \\
{[2010]} \\
{[1]}\end{array}$ & 56 & M & $\begin{array}{l}\text { Incidental discovery } \\
\text { of a large left } \\
\text { thyroid lobe nodule } \\
\text { on } \mathrm{CT}\end{array}$ & 4.9 & $\begin{array}{l}\text { Burkitt-like } \\
\text { large B-cell } \\
\text { lymphoma }\end{array}$ & & $\begin{array}{l}\text { Left lobe thyroidectomy. } \\
\text { After diagnosis, The } \\
\text { patient was treated with } \\
8 \text { cycles of intensive } \\
\text { chemotherapy } \\
\text { (cyclophosphamide, } \\
\text { vincristine, doxorubicine, } \\
\text { and dexamethasone) }\end{array}$ & 1 & $\begin{array}{l}\text { Reduction of all } \\
\text { lesions with } \\
\text { improvement of } \\
\text { symptoms. }\end{array}$ \\
\hline $\begin{array}{l}\text { Kalinyak et al. } \\
{[2006]} \\
{[2]}\end{array}$ & 53 & M & $\begin{array}{l}\text { Tracheal } \\
\text { compressive } \\
\text { symptoms from a } \\
\text { rapidly expanding } \\
\text { thyroid mass }\end{array}$ & 6 & $\begin{array}{l}\text { Burkitt } \\
\text { lymphoma }\end{array}$ & & $\begin{array}{l}\text { Rituxan and CHOP } \\
\text { therapy, changed to } \\
\text { hyper-CVAD-R chemother- } \\
\text { apy. The patient also re- } \\
\text { ceived a single dose of } \\
\text { intrathecal methotrexate }\end{array}$ & 27 & $\begin{array}{l}\text { Patient free of } \\
\text { disease after } \\
\text { end of } \\
\text { treatment }\end{array}$ \\
\hline $\begin{array}{l}\text { Kandil et al. } \\
{[2012]} \\
{[10]}\end{array}$ & 60 & $\mathrm{~F}$ & $\begin{array}{l}\text { Rapidly expanding } \\
\text { thyroid mass with } \\
\text { airway compression } \\
\text { and difficulty in } \\
\text { swallowing }\end{array}$ & 8.7 & $\begin{array}{l}\text { Burkitt-like } \\
\text { lymphoma } \\
\text { (B-cell } \\
\text { lymphoma, } \\
\text { unclassifiable) }\end{array}$ & & $\begin{array}{l}\text { Rituximab, } \\
\text { Cyclophosphamide, } \\
\text { Mensa, Vincristine and } \\
\text { Doxorubicin }\end{array}$ & & $\begin{array}{l}\text { Successfully } \\
\text { treated with } \\
1 \text { cycle of } \\
\text { appropriate } \\
\text { therapeutic } \\
\text { chemotherapy }\end{array}$ \\
\hline $\begin{array}{l}\text { Cooper et al. } \\
{[2014]} \\
{[14]}\end{array}$ & 14 & M & $\begin{array}{l}\text { Large predominantly } \\
\text { left-sided firm thy- } \\
\text { roid swelling, with a } \\
\text { 3-month history of } \\
\text { malaise, lethargy, } \\
\text { and weight loss }\end{array}$ & 6.7 & $\begin{array}{l}\text { Burkitt } \\
\text { lymphoma }\end{array}$ & $\mathrm{t}(8 ; 14)$ & $\begin{array}{l}\text { COP and prednisolone } \\
\text { followed by } 2 \text { courses of } \\
\text { COPADM, prednisolone } \\
\text { and two courses of CYM } \\
\text { chemotherapy. This was } \\
\text { accompanied by } \\
\text { intrathecal chemotherapy }\end{array}$ & 36 & $\begin{array}{l}\text { Disease free } \\
3 \text { years after } \\
\text { end of } \\
\text { treatment }\end{array}$ \\
\hline $\begin{array}{l}\text { Yildiz et al. } \\
{[2012]} \\
{[22]}\end{array}$ & 31 & M & $\begin{array}{l}\text { Rapidly enlarging } \\
\text { mass on the fore } \\
\text { neck }\end{array}$ & 4 & $\begin{array}{l}\text { Burkitt } \\
\text { lymphoma }\end{array}$ & & R-Hyper-CVAD therapy & 6 & $\begin{array}{l}\text { PET-CT scans } \\
\text { performed after } \\
\text { chemotherapy } \\
\text { and at the 6- } \\
\text { month follow- } \\
\text { up were normal }\end{array}$ \\
\hline $\begin{array}{l}\text { Mweempwa et al. } \\
\text { [2013] } \\
\text { [24] }\end{array}$ & 58 & $\mathrm{~F}$ & $\begin{array}{l}\text { Background of } \\
\text { benign goiter } \\
\text { presented with a } \\
\text { rapidly enlarging } \\
\text { thyroid mass, } \\
\text { causing dysphagia } \\
\text { and dyspnea }\end{array}$ & 8 & $\begin{array}{l}\text { Burkitt } \\
\text { lymphoma }\end{array}$ & $\mathrm{t}(8 ; 14)$ & $\begin{array}{l}\text { Modified Magrath protocol } \\
\text { for Burkitt's lymphoma, } \\
\text { low risk disease, which } \\
\text { involved having } 3 \text { cycles } \\
\text { of R-CODOX-M }\end{array}$ & 4 & $\begin{array}{l}\text { Complete } \\
\text { resolution of } \\
\text { the tumour } \\
\text { mass, } 4 \text { weeks } \\
\text { after end of } \\
\text { treatment }\end{array}$ \\
\hline $\begin{array}{l}\text { Liying et al. } \\
\text { [2014] } \\
{[30]}\end{array}$ & 8 & M & $\begin{array}{l}\text { Mass in the right } \\
\text { anterior neck with } \\
\text { difficulty in } \\
\text { swallowing }\end{array}$ & 4 & $\begin{array}{l}\text { Burkitt } \\
\text { lymphoma }\end{array}$ & $\mathrm{t}(8 ; 14)$ & $\begin{array}{l}\text { Right lobe thyroidectomy. } \\
\text { After diagnosis, the patient } \\
\text { underwent alternate R-B- } \\
\text { NHL-BFM-90-A and R-B- } \\
\text { NHL-BFM-90-B treatment, } \\
\text { for } 4 \text { cycles each }\end{array}$ & 48 & $\begin{array}{l}\text { After } 4 \text { years of } \\
\text { follow-up, the } \\
\text { patient appears } \\
\text { well and re- } \\
\text { mains free of } \\
\text { disease }\end{array}$ \\
\hline
\end{tabular}

suggest PTL, based essentially upon ultrasound findings of internal echoes, borders, and posterior echoes. For example, Enhanced posterior echoes help in distinguishing lymphoma from other types of thyroid lesions [26, 27].

Once PTL is suspected based upon clinical presentation and ultrasound findings, the next step in diagnosis is biopsy. Traditionally, open surgical biopsy was felt to be necessary to differentiate thyroid lymphoma from thyroiditis and anaplastic carcinoma. However, with recent advances in immunophenotypic analysis, the accuracy of fine-needle aspiration (FNA) has improved. These advances in diagnosis of PTL mirror those seen with systemic lymphomas with a reported accuracy rate of FNA of $80-100 \%$. Nevertheless, there are still challenges in 
FNA diagnosis of thyroid lymphoma, particularly due to the histological similarities with thyroiditis and the high coincidence of these pathologies within the same gland, which results in increased false-negative rates from sampling error [26].

Histologically, the tumour cells of BL are medium-sized cells (nuclei similar or smaller to those of histiocytes) and show a diffuse monotonous pattern of growth. The cells appear to be cohesive but sometimes exhibit squared-off borders of retracted cytoplasm. The nuclei are round with finely clumped and dispersed chromatin, with multiple basophilic medium-sized, paracentrally situated nucleoli. The cytoplasm is deeply basophilic and usually contains lipid vacuoles. The tumour has an extremely high proliferation fraction (many mitotic figures) as well as a high fraction of apoptosis. A "starry sky" pattern is usually present, which is imparted by numerous benign macrophages that have ingested apoptotic tumour cells [28].

In Burkitt lymphoma, the tumour cells express moderate to strong levels of membrane IgM with light chain restriction and B-cell-associated antigens (CD19, CD20 and CD22), CD10, BCL6, c-MYC and CD38. The neoplastic cells are usually negative or only weakly positive for BCL2 and are uniformly TdT and MUM-1/IRF-4 negative. Nearly $100 \%$ of the cells are positive for Ki67. There are very few admixed T-cells [12, 28-30]. In the present case, the immunophenotype of the atypical lymphoid cells was consistent with these features.

Burkitt lymphoma is characterized at the molecular level by a reciprocal translocation involving the $c-M Y C$ proto-oncogene, which normally resides on chromosome $8 \mathrm{q} 24$. The most common translocation in Burkitt lymphoma is a $\mathrm{t}(8 ; 14)(\mathrm{q} 24 ; \mathrm{q} 32)$, which results in the translocation of $c-M Y C$ to the B-cell heavy-chain gene locus on chromosome 14q32. This translocation occurs in approximately $80 \%$ of Burkitt lymphoma cases regardless of the clinical setting. Other variant translocations involve the translocation of $c-M Y C$ to the kappa light chain locus on chromosome 2 , t (2;8) (p12;q24), which occurs in approximately $15 \%$ of cases, and translocation of $c-M Y C$ to the lambda light-chain locus on chromosome $22, \mathrm{t}(8 ; 22)(\mathrm{q} 24 ; \mathrm{q} 11)$, which occurs in approximately $5 \%$ of cases [12, 28, 31].

In addition, it has been confirmed that the occurrence of BL is associated with viral infections, particularly EBV infection. However, the EBV detection rates in different subtypes of BL also vary [32]. EBV infection is detected in the vast majority of endemic BL and $30 \%$ of sporadic BL [12, 30, 32].

Treatment of Burkitt lymphoma in most centers is guided by the FAB LMB study (cooperative study between the Children's Cancer Group, the Societé Francaise d'Oncologie Pediatrique, and the UK Children's Cancer Study Group) [33, 34]. The former consists of initial cytoreduction with cyclophosphamide, prednisolone, and vincristine, followed by more intensive chemotherapy in varying combinations containing doxorubicin, alkylators, vincristine, etoposide and therapy directed to eradicate or to prevent CNS disease such as high dose methotrexate [3, 12].

Aggressive high-dose therapy is needed for adult Burkitt lymphoma. However, interpretation of response is difficult because most studies of this approach have been done with a single protocol in mainly young adults. The regimen generally used in the UK and USA is cyclophosphamide, vincristine, doxorubicin, and highdose methotrexate alternating with ifosfamide, etoposide, and high-dose cytarabine [12].

The use of a less toxic dose adjusted EPOCH (etoposide, prednisone, vincristine, cyclophosphamide, adriamycin) plus rituximab (DA-REPOCH) led to an event free survival of $96 \%$ and an overall survival of $100 \%$ with a median follow up to 86 months in a small studay that included 19 HIV negative patients [35]. The use of rituximab (anti-CD20) in primary therapy has been assessed and a randomized clinical trial including 257 patients demonstrated that the addition of rituximab to the LMB regimen improved the event free survival and the overall survival without adding more toxicities [4].

\section{Conclusions}

In summary, the current study presents a case of sporadic primary $\mathrm{BL}$ of the thyroid occurring in a seventyyear-old male, which exhibited the typical morphological features and immunophenotype of BL and which, to the authors' knowledge, is the first case of BL of the thyroid gland to be reported in Morocco. We also emphasize here the importance of considering lymphoma when dealing with a thyroid mass, as its management is different from that of other thyroid pathologies and delaying treatment has an impact on prognosis.

\section{Consent}

Written informed consent was obtained from the patient's family for publication of this case report and any accompanying images. A copy of the written consent is available for review by the Editor of this journal.

\section{Ethics approval and consent to participate}

Not applicable.

\section{Abbreviations}

BL: Burkitt lymphoma; CT: computerized tomography; EBV: epstein-barr virus; PTL: primary thyroid lymphoma.

Competing interests

The authors declare that they have no competing interests. 


\section{Authors' contributions}

$M A, I B, E M M, S R$ and MA analyzed and interpreted the patient data, drafted the manuscript and made the figures. $M A, A B, M B$ and $M O$ performed the histological examination and proposed the study. MA, AAB and MO made substantial contributions to conception and design, and revised the manuscript. All authors of this paper have read and given final approval of the version to be published.

\section{Author details}

'Department of Pathology, Military General Hospital Mohammed V, Mohammed V Souissi University - Faculty of Medicine and Pharmacy of Rabat, Hay Riad, Rabat 10000, Morocco. ${ }^{2}$ Department of Clinical Haematology, Military General Hospital Mohammed V, Mohammed V Souissi University - Faculty of Medicine and Pharmacy of Rabat, Hay Riad, Rabat 10000, Morocco. ${ }^{3}$ Department of Otorhinolaryngology, Military General Hospital Mohammed V, Mohammed V Souissi University - Faculty of Medicine and Pharmacy of Rabat, Hay Riad, Rabat 10000, Morocco.

Received: 1 March 2016 Accepted: 5 May 2016

Published online: 11 May 2016

\section{References}

1. Camera A, Magri F, Fonte $R$, et al. Burkitt-like lymphoma infiltrating a hyperfunctioning thyroid adenoma and presenting as a hot nodule. Thyroid. 2010;20(9):1033-6.

2. Kalinyak JE, Kong CS, McDougall IR. Burkitt's lymphoma presenting as a rapidly growing thyroid mass. Thyroid. 2006;16(10):1053-7.

3. Murphy SB. Classification, staging and end results of treatment of childhood non- Hodgkin's lymphomas: dissimilarities from lymphomas in adults. Semin Oncol. 1980;7:332-9.

4. Ribrag V, Koscielny $\mathrm{S}$, Bouabdallah $\mathrm{K}$, et al. Addition of rituximab improves outcome of HIV negative patients with Burkitt lymphoma treated with the LMBA protocol: results of the randomized intergroup (GRAALL-lysa) LMBA02 protocol [abstract]. Blood. 2012;120(21):Abstract 685.

5. Derringer GA, Thompson LD, Frommelt RA, Bijwaard KE, Heffess CS, Abbondanzo SL. Malignant lymphoma of the thyroid gland: a clinicopathologic study of 108 cases. Am J Surg Pathol. 2000:24:623e39.

6. Pedersen RK, Pedersen NT. Primary non-Hodgkin's lymphoma of the thyroid gland: a population based study. Histopathology. 1996;28(1):25-32.

7. Earnest LM, Cooper DS, Sciubba JJ, Tufano RP. Thyroid MALT lymphoma in patients with a compressive goiter. Head Neck. 2006;28(8):765-70.

8. $\quad$ Yang L, Wang A, Zhang Y, Mu Y. 12 cases of primary thyroid lymphoma in China. J Endocrinol Investig. 2015;38(7):739-44.

9. Alzouebi M, Goepel JR, Horsman JM, et al. Primary thyroid lymphoma: the 40 year experience of a UK lymphoma treatment centre. Int J Oncol. 2012; 40(6):2075-80

10. Kandil E, Safah $H$, Noureldine $S$, et al. Burkitt-like lymphoma arising in the thyroid gland. Am J Med Sci. 2012;343(1):103-5.

11. Ha CS, Shadle KM, Medeiros LJ, Wilder RB, Hess MA, Cabanillas F, et al. Localized non-Hodgkin lymphoma involving the thyroid gland. Cancer. 2001;91:629e35.

12. Molyneux EM, Rochford R, Griffin B, Newton R, Jackson G, Menon G, Harrison CJ, Israels T, Bailey S. Burkitt's lymphoma. Lancet. 2012;379(9822): 1234-44.

13. Jaff ES. The 2008 WHO classifi cation of lymphomas: implications for clinical practice and translational research. Hematology Am Soc Hematol Educ Program. 2009;1:523-31.

14. Cooper K, Gangadharan A, Arora RS, Shukla R, Pizer B. Burkitt lymphoma of thyroid gland in an adolescent. Case Rep Pediatr. 2014;2014(187467):3.

15. Ansell SM, Grant CS, Habermann TM. Primary thyroid lymphoma. Semin Oncol. 1999;26(3):316-23.

16. Widder S, Pasieka JL. Primary thyroid Iymphomas. Curr Treat Options Oncol. 2004;5:307e13

17. Holm LE, Bloomgren H, Lowhagen T. Cancer risks in patients with chronic lymphocytic thyroiditis. N Engl J Med. 1985;312:601-4.

18. Matsuzuka F, Miyauchi A, Katayama S, Narabayashi I, Ikeda H, Kuma K, Sugawara M. Clinical aspects of primary thyroid lymphoma: diagnosis and treatment based on our experience of 119 cases. Thyroid. 1993;3(2):93-9.

19. Isaacson PG. Lymphoma of the thyroid gland. Curr Top Patyhol. 1997;91:1e14.
20. Kossev P, Livolsi V. Lymphoid lesions of the thyroid: review in light of the revised Europeane American lymphoma classification and upcoming World Health Organization classification. Thyroid. 1999;9:1273e80.

21. Saxena A, Alport EC, Moshynska O, Kanthan R, Boctor MA. Clonal B cell populations in a minority of patients with Hashimoto's thyroiditis. J Clin Pathol. 2004;57:1258e63.

22. Yildiz I, Sen F, Toz B, et al. Primary Burkitt's lymphoma presenting as a rapidly growing thyroid mass. Case Rep Oncol. 2012;5(2):388-93.

23. Sarinah B, Hisham AN. Primary lymphoma of the thyroid: diagnosis and therapeutic considerations. Asian J Surg. 2010;33(1):20-4.

24. Mweempwa A, Prasad J, Islam S. A rare neoplasm of the thyroid gland. N Z Med J. 2013;126(1369):75-8.

25. Albert S. Primary Burkitt lymphoma of the thyroid. Ear Nose Throat J. 2013; 92(12):E1-2

26. Stein SA, Wartofsky L. Primary thyroid Iymphoma: a clinical review. J Clin Endocrinol Metab. 2013;98(8):3131-8.

27. Ota H, Ito $Y$, Matsuzuka F, et al. Usefulness of ultrasonography for diagnosis of malignant lymphoma of the thyroid. Thyroid. 2006;16:983-7.

28. Swerdlow SH, Campo E, Harris NL, et al. WHO classification of tumours of haematopoietic and lymphoid tissues. Lyon: IARC Press; 2008.

29. Chuang SS, Ye H, Du MQ, Lu CL, Dogan A, Hsieh PP, Huang WT, Jung YC. Histopathology and immunohistochemistry in distinguishing Burkitt lymphoma from diffuse large B-cell lymphoma with very high proliferation index and with or without a starry-sky pattern: a comparative study with EBER and FISH. Am J Clin Pathol. 2007;128(4):558-64.

30. Liying Z, Lanxiang G, Guang L, Luping W, Chunwei X, Lin L, Yuwang T, Huiru F, Zhe G. Primary Burkitt's lymphoma of the thyroid without EpsteinBarr virus infection: a case report and literature review. Oncol Lett. 2014;7(5): 1519-24.

31. Hecht JL, Aster JC. Molecular biology of Burkitt's lymphoma. J Clin Oncol. 2000;18(21):3707-21.

32. Queiroga EM, Gualco G, Chioato L, Harrington WJ, Araujo I, Weiss LM, Bacchi CE. Viral studies in Burkitt lymphoma: association with Epstein Barr virus but not HHV 8. Am J Clin Patho. 2008;130:186-92.

33. Patte C, Philip T, Rodary C, et al. High survival rate in advanced-stage B-cell lymphomas and leukemias without CNS involvement with a short intensive polychemotherapy: results from the French pediatric oncology society of a randomized trial of 216 children. J Clin Oncol. 1991;9(1):123-32.

34. Patte C, Auperin A, Michon J, et al. The Societe Francaise d'Oncologie pediatrique LMB89 protocol: highly eff ective multiagent chemotherapy tailored to the tumor burden and initial response in 561 unselected children with B-cell lymphomas and L3 leukemia. Blood. 2001;97:3370-79.

35. Dunleavy K, Pittaluga S, Shovlin M, et al. Low-intensity therapy in adults with Burkitt's lymphoma. N Engl J Med. 2013:369(20):1915-25.

\section{Submit your next manuscript to BioMed Central and we will help you at every step:}

- We accept pre-submission inquiries

- Our selector tool helps you to find the most relevant journal

- We provide round the clock customer support

- Convenient online submission

- Thorough peer review

- Inclusion in PubMed and all major indexing services

- Maximum visibility for your research

Submit your manuscript at www.biomedcentral.com/submit
) Biomed Central 